Nippon Suisan Gakkaishi $\quad$ 80(5), 823 (2014)

\title{
シンポジウム記録 スサビノリの持続的生産への挑戦
}

\section{I -2. 関東におけるノリ養殖の現状と課題}

林 俊裕

千葉県水産総合研究センター東京湾漁業研究所

I-2. Current situation and problems of Nori mariculture in Kanto area

TOSHIHIRO HAYASHI

Tokyo Bay Fisheries Research Laboratory, Chiba Prefectural Fisheries Research Center, Futtsu, Chiba 293-0042, Japan

\section{1. ノリ養殖の現状}

関東では東京湾の千葉県抢よび神奈川県沿岸でノリ養 殖が行なわれ，年間 $3 \sim 4$ 億枚の乾のりが作られてい る。そのうち約 $97 \%$ が生産されている千葉県における ノリ養殖の現状について報告する。

千葉県の乾のり生産枚数は 1990 年代から 2000 年代 はじめまでは年間 4 5 億枚で比較的安定していた。し かし, 近年は 2001 年度の 5 億 1 千万枚をピークに生産 は減少傾向に転じ 2012 年度の生産枚数は約 3 億枚で, 2001 年度の $59 \%$ であった。出荷金額も同様に 2000 年 代はじめまでは 50 億円を上回る年が多かったが以降は 減少傾向を示し, 2012 年度は約 28 億円にとどまってい る。県全体の養殖施設規模は 1993 年度の約 10 万柵（4 尺 10 間網）から 2013 年度は約 5 万柵に半減。経営体 数も年々減少を続け, 1993 年度の 709 経営体から 2013 年度は 262 経営体へと約 $1 / 3$ に減少した。

\section{2. 問題点之課題}

\section{（1）環境変化}

のり養殖技術の進歩や省力化による規模の拡大によっ て, 千葉県に扔いては, 2000 年頃までは, 経営体数が 減少しても生産枚数が維持されていた。しかし，2000 年以降は水温下降期（11 12 月）打よび水温上昇期（3 ４月）の生産が顕著に減少し生産枚数の維持が困難と なっている。1)

水温下降期については, 長期的な海水温の上昇による 生産開始時期の遅れや, 生産開始後の水温降下速度の鈍
化が, 生産量抢よび健全な種網確保の面からのり養殖業 へ悪影響を与えていることが知られている。22この対策 として千葉県では高水温耐性品種「ちばの輝き」を開発 し普及している。また環境条件とノリ生育との関連調査 を行い水温下降期の好適漁場の把握に取り組んでいる。

水温上昇期については, 東京湾の溶存無機態リン (DIP) 濃度の長期的な減少に加え珪藻赤潮発生種の変 化や発生頻度の増加がもたらす「色落ちのり」の増加が 生産減少の主な原因であると考えられている。3,4)この対 策としては, ダムからの上乗せ放流によるノリ養殖漁場 への栄養塩添加に関する調査や栄養塩レベルとノリ葉体 の色調との関連調査等を実施しているが抜本的な対策に は至っていないのが現状である。

\section{(2) 価格形成}

千葉県では豊富な栄養特性を背景に養殖期間中の頻繁 な網交換（通常 5〜 6 期作）や地先で育つアオノリの活 用など特色を生かしたノリ作りを行ない，贈答用や寿司 用などの高級品から業務用まで多様な用途の製品を出荷 してきた。それによって，これまでは 10 円/枚以上の 平均単価を維持し, 県別に見た平均単価では常に全国 1 〜2 位の座を占めていた。ところが，近年は家庭用・贈 答用の需要減少で単価の維持が困難となり，2012 年度 の平均単価は 9.0 円/枚まで下落した。千葉県ののり養 殖業者はこれまで「高品質・高価格の製品づくり」によ って経営向上を目指してきたが，今後はさらに「低コス トでの養殖」への意識転換が必要となっている。

\section{文献}

1）林 俊裕. 生産性から見た千葉県における近年ののり養殖 生産量減少の特徵について. 千葉水総研報 2010; 5: 3134.

2) 石井光廣, 長谷川健一, 柿野 純. 千葉県データセットか ら見た東京湾に打ける水質の長期変動. 水産海洋研究 2008; 72(3): 189-199.

3）石井光廣, 長谷川健一, 松山幸彦. 東京湾のノリ生産に影 響を及ぼす環境要因 : 栄養塩類の長期変動および最近の珪 藻赤潮発生. 水産海洋研究 2008; 72(1): 22-29.

4）長谷川健一, 林 俊裕. 東京湾の栄養塩環境とノリ養殖. 海洋と生物 2009; 181: 161-164. 